\title{
Electron Microscopic Localization of Type I Protein Kinase C in Rat Purkinje Cells
}

\author{
Akiko Kose, ${ }^{1}$ Naoaki Saito, ${ }^{1}$ Hiroshi Ito, ${ }^{2}$ Ushio Kikkawa, ${ }^{3}$ Yasutomi Nishizuka, ${ }^{3}$ and Chikako Tanaka' \\ Departments of 'Pharmacology, ${ }^{2}$ Pathology, and ${ }^{3 B}$ Biochemistry, Kobe University School of Medicine, Kobe 650, Japan
}

\begin{abstract}
A monoclonal antibody against protein kinase C (PKC) was used for immunocytochemical studies of the type I PKC encoded by $\gamma$-cDNA sequence ( $\gamma$-subspecies) in rat Purkinje cells. Dense $\gamma$-subspecies-like immunoreactivity was found on the cell membrane and in the cytoplasm except within cell organelles of the perikaryon, dendrites, axon, and axon terminals. The nucleus was also stained but less heavily, and the nucleoli remained unstained. Synaptic vesicles in the axon terminals were densely stained. The results suggest that $\gamma$-subspecies might be functionally involved in modulation of nuclear function and of pre- and postsynaptic functions including transmitter release in the rat Purkinje cells.
\end{abstract}

The physiological importance of protein kinase $\mathrm{C}(\mathrm{PKC})$ in cell surface signal transduction is now widely accepted and well documented (for reviews, see Nishizuka, 1984a, b, 1986). The enzyme is distributed ubiquitously in tissues and organs, with the highest level of activity in the brain. Recent analysis of complementary DNA (cDNA) clones has predicted the existence of multiple, at least $4(\alpha, \beta \mathrm{I}, \beta \mathrm{II}$, and $\gamma)$, subspecies of PKC with closely related structures in the mammalian brain (Coussens et al., 1986; Knopf et al., 1986; Ono et al., 1986a, b, 1987a; Parker et al., 1986; Ohno et al., 1987). cDNA clones designated $\alpha, \beta, \gamma$ (Coussens et al., 1986) are shown to be encoded on different chromosomes, whereas Ono et al. designated $\beta \mathrm{I}$ and $\beta \mathrm{II}$ for 2 subspecies derived from a single gene by alternative splicing (Ono et al., 1986b, 1987a). This integrated nomenclature of $\alpha, \beta \mathrm{I}, \beta \mathrm{II}$, and $\gamma$ (Kikkawa et al., 1987a, b; Ono et al., 1987a) will be used hereafter for the 4 cDNA clones. Although once considered as a single entity, the purified PKC of rat brain has been resolved into 3 distinct fractions, types I, II, and III, by hydroxyapatite column chromatography (Huang et al., 1986; Kikkawa et al., 1987a; Ono et al., 1987a). Comparison of each fraction from rat brain with the 4 subspecies of PKC that were separately expressed in COS 7 cclls transfected with the respective $c D N A$-containing plasmids has revealed that type I corresponds to the enzyme encoded by $\gamma$-sequence, type II is a mixture of the 2 subspecies determined by $\beta \mathrm{I}-$ and $\beta \mathrm{II}-$

Received Dec. 8, 1987; revised Mar. 4, 1988; accepted Mar. 9, 1988

This work was supported by research grants from the Scientific Research Fund of the Ministry of Education, Science and Culture and the Ministry of Health and Welfare, Japan; Muscular Dystrophy Association; Yamanouchi Foundation for Research on Metabolic Disorders; Merck Sharp \& Dohme Research Laboratories; Biotechnology Laboratories of Takeda Chemical Industries; and Meiji Institute of Health Sciences. We wish to thank S. Tanioka for his valuable advice on the electron microscopic techniques.

Correspondence should be addressed to C. Tanaka at the above address.

Copyright (C) 1988 Society for Neuroscience $0270-6474 / 88 / 114262-07 \$ 02.00 / 0$ sequences, and type III has the structure encoded by $\alpha$-sequence (Kikkawa et al., 1987a; Ono et al., 1987a). Very recently, 3 more cDNA clones of PKC family $(\delta, \epsilon, \zeta)$ have been identified (Ono et al., 1987b). The different physiological roles of these subspecies of PKC, however, have not been explored. We have prepared 3 monoclonal antibodies against rat brain $\mathrm{PKC}$ isolated from the soluble fraction, CKI-33, CKI-97, and CKII-90 (Kitano et al., 1987). A mixture of these antibodies was used in our previous report to show the entire immunocytochemical map of protein kinase $\mathrm{C}$ in the rat brain, which predominantly illustrates the distribution of type I PKC (Saito et al., 1988). Using CKI-97, which reacts strongly and preferentially with type I PKC with $\gamma$-sequence ( $\gamma$-subspecies), this paper reports the detailed localization of this enzyme in Purkinje cells of the rat cerebellar cortex by electron microscopic analysis.

\section{Materials and Methods}

Preparation of the monoclonal antibody. The monoclonal antibody was obtained as described by Kitano et al. (1987), and its specificity was determined as described by Hashimoto et al. (1988). In brief, PKC was purified from the soluble fraction of rat brain, and a monoclonal antibody against PKC (CKI-97) was obtained by the routine method through immunizing mice with the purified enzyme. Immunoprecipitation and Western blot analysis indicated that this antibody reacts strongly and preferentially with the type I PKC having the structure encoded by $\gamma$-sequence.

Preparation of tissues and immunocytochemical staining. The following steps were carried out at $4^{\circ} \mathrm{C}$ unless otherwise indicated. Wistar rats weighing 150-200 gm were anesthetized with pentobarbital $(40 \mathrm{mg} / \mathrm{kg})$ and perfused through the left ventricle at a flow rate of $15 \mathrm{ml} / \mathrm{min}$. The blood was washed out with $30 \mathrm{ml}$ of $0.9 \% \mathrm{NaCl}$, and the brain was perfused with $200 \mathrm{ml}$ of the fixative, which contained $4 \%$ paraformaldehyde (FA), $0.5 \%$ glutaraldehyde, and $0.2 \%$ picric acid (PA) in $0.1 \mathrm{M}$ phosphate buffer $(\mathrm{PB})$. The perfused brain was dissected from the cranial cavity, cut into blocks, immersed for $2 \mathrm{~d}$ in a fxative containing $4 \%$ FA and $0.2 \%$ PA, and washed for $1 \mathrm{~d}$ with $30 \%$ sucrose in $0.1 \mathrm{M}$ PB. Then, the small brain blocks were frozen in liquid nitrogen, thawed, and cut on a Vibratome ( $40 \mu \mathrm{m}$ thick). Sagittal sections of the cerebellum were incubated for 20 min with $0.3 \%$ hydrogen peroxide in $0.1 \mathrm{M}$ PBS to inhibit the endogenous peroxidase, and with $20 \%$ normal goat serum (NGS) in PBS for $20 \mathrm{~min}$ to block the nonspecific binding sites of proteins. The sections were then incubated for $18 \mathrm{hr}$ with the monoclonal antibody (CKI-97) in PBS containing 5\% NGS (PBS-NGS) to yield a final concentration of $5 \mu \mathrm{g} / \mathrm{ml} \mathrm{IgG}$. The sections were washed with PBS-NGS, incubated for $18 \mathrm{hr}$ with goat anti-mouse IgG (Miles) diluted 1:100, washed, and incubated for $2 \mathrm{hr}$ with mouse peroxidaseantiperoxidase complex (PAP; Miles) diluted 1:100. After rinsing 3 times, the preparations were incubated with $0.02 \%$ 3,3-diaminobenzidine (Sigma) dissolved in $50 \mathrm{~mm}$ Tris- $\mathrm{HCl}(\mathrm{pH} \mathrm{7.4)}$. The antigen (type I PKC) was then localized by adding $0.005 \%$ hydrogen peroxide in the solution and reacted for $5-15 \mathrm{~min}$ at room temperature. The stained sections were postfixed for $1 \mathrm{hr}$ in $2 \%$ osmium tetroxide in $0.1 \mathrm{M}$ PBS, dehydrated in graded alcohol, and flat-embedded on siliconized slides in resin (Epon 812 ). After polymerization at $60^{\circ} \mathrm{C}$ for $48 \mathrm{hr}$, densely stained areas were selected at first without a microscope and were con- 


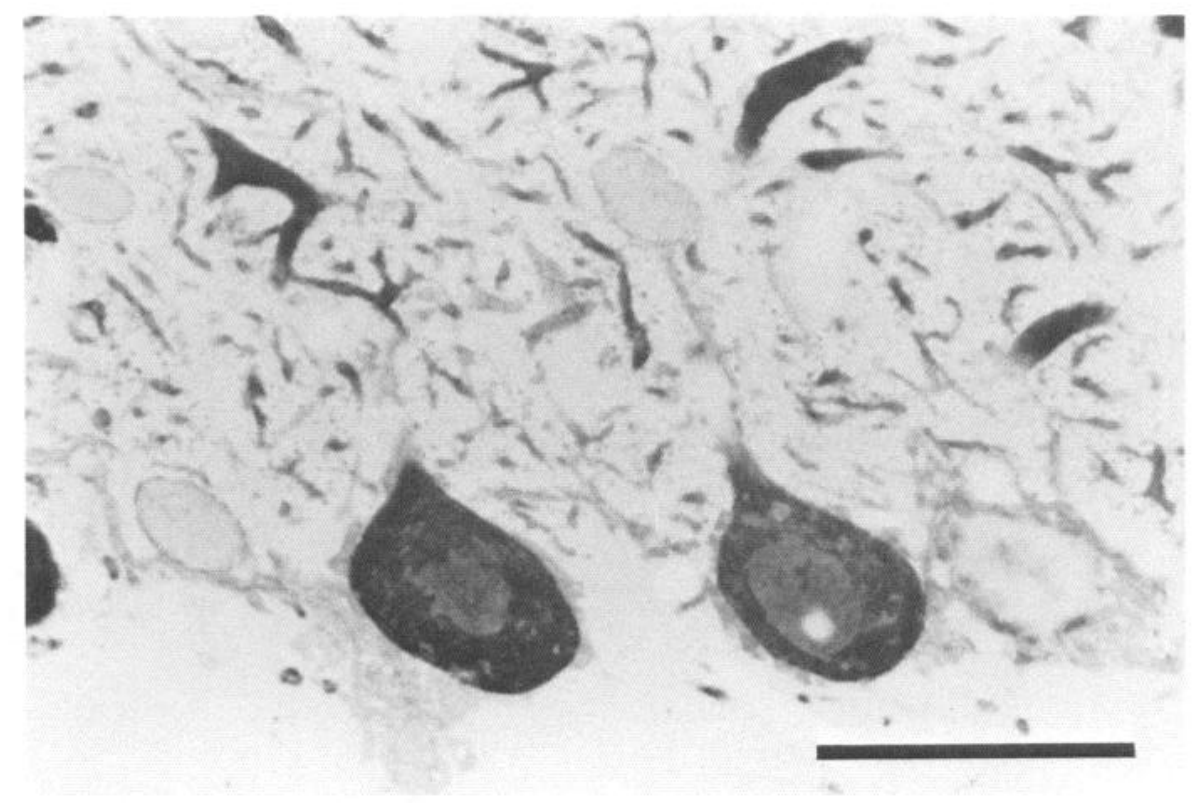

Figure 1. Photomicrograph from the molecular layer of the cerebellum in a sagittal section. Dense immunoreactivity is associated with all cytoplasm of Purkinje cell, perikarya, dendrites, and nucleoplasm but not with the nucleoli. Scale bar, $50 \mu \mathrm{m}$.

firmed with a microscope. Selected areas were cut off and attached to Epon supports for further sectioning on a Reichert-Jung Ultracut E ultramicrotome. Semithin sections ( $1 \mu \mathrm{m}$ thick) were viewed and photographed under a Zeiss microscope. Ultra-thin sections were cut and mounted on Formvar-coated, single-slot grids, stained with $1 \%$ uranyl acetate in 50\% ethanol, and examined with a Hitachi H-600A electron microscope at $100 \mathrm{kV}$.

\section{Results and Discussion}

Type I PKC is the dominant type of PKC present in the cerebellum and apparently is not found in tissue other than brain and spinal cord (Shearman et al., 1987). At the light microscopic level, type I PKC-like immunoreaction is localized exclusively to neurons, with the Purkinje cell being one of the most densely stained cell types in the brain (Saito et al., 1988). The Purkinje neuron is entirely immunoreactive, with most of the intense immunoreactivity located in the perikaryal and dendritic cytoplasm. The immunoreactivity in the dendrites was followed from the smooth primary dendrites to the short dendritic spines. The axon was also stained from the pre-axon to the terminals. There is less reactivity in the nuclei, and no immunoreactivity is found in the nucleoli (Fig. 1).

Electron microscopic observations of the perikarya of Purkinje neurons showed the densest immunoreactivity to be on the cell membrane and in the cytoplasm. In some cells, the cell membrane is more densely stained than in others. This distribution may be a reflection of the fundamental role of $\gamma$-subspecies in receptor-mediated signal transduction at the cell surface. Moderately dense reaction was found in the nucleoplasm, but the nucleoli showed no or faint immunoreactivity (Fig. 2A). The presence of type I PKC in the nucleoplasm is probably consistent with its association with nuclear functions. PKC is suggested to regulate gene expression in peripheral cells (Kraft et al., 1987; Philippe et al., 1987). Although type I PKC is a brain-specific enzyme, it also might be concerned with gene expression in neurons. There was no immunoreactivity in the control sections, which were stained without the primary antibody (CKI-97) (Fig. 2B).

At high magnification, immunoreactive products were ob- served throughout the perikaryal cytoplasm except for inside the cell organelles (Fig. $3 A$ ). Heavy staining was observed along the outer membrane of cell organelles such as mitochondria, endoplasmic reticulum, and the Golgi apparatus. Moderate immunoreactivity was also associated with the membranes of smooth-walled vesicles clustered at borders of the Golgi apparatus. The nuclear envelope remained poorly stained compared with the densely stained cell membrane. Both immunopositive and immunonegative terminals making synaptic contacts with the cell body were seen at the base of Purkinje cells.

In the dendrites of Purkinje cells, dense immunoreactivity was present throughout the cytoplasm but not within the organelles. The cytoplasmic membrane of the dendrites was also stained, and stained dendritic spines scattered around the primary dendrites were seen to form numerous synaptic contacts with immunonegative terminals (Fig. $3 B$ ). These synapses are differentiated as Gray's Type I synapses, because a thicker undercoating is seen in the immunoreactive dendrite, which is the postsynaptic side. This may be consistent with the fact that the dendritic spines of Purkinje cells receive input from the parallel fibers of granule cells, which are thought to be excitatory and glutamatergic (Young et al., 1974; Sandoval and Cotman, 1978).

Figure 4 shows the immunoreactive axon among nonimmunoreactive axons in the white matter of the cerebellar cortex. Intense immunoreactivity was seen in the axoplasm but not in the myelin sheath. These axons are projecting from the base of Purkinje cells, running through the granular layer into the white matter (Fig. 4, inset).

In the deep cerebellar nuclei, there were large immunonegative cell bodies surrounded almost exclusively by immunopositive terminals (Fig. 5A), which possessed densely immunoreactive synaptic vesicles. The presence of the immunoreactive type I PKC at both the smooth-walled vesicles of the Golgi apparatus, as well as synaptic vesicles, suggest that this subspecies is a component of the vesicles before budding from the Golgi apparatus and being transported to the terminals. It is also possible that $\mathrm{PKC}$ is associated with vesicular function such as vesicular release of GABA from Purkinje cells. We have 


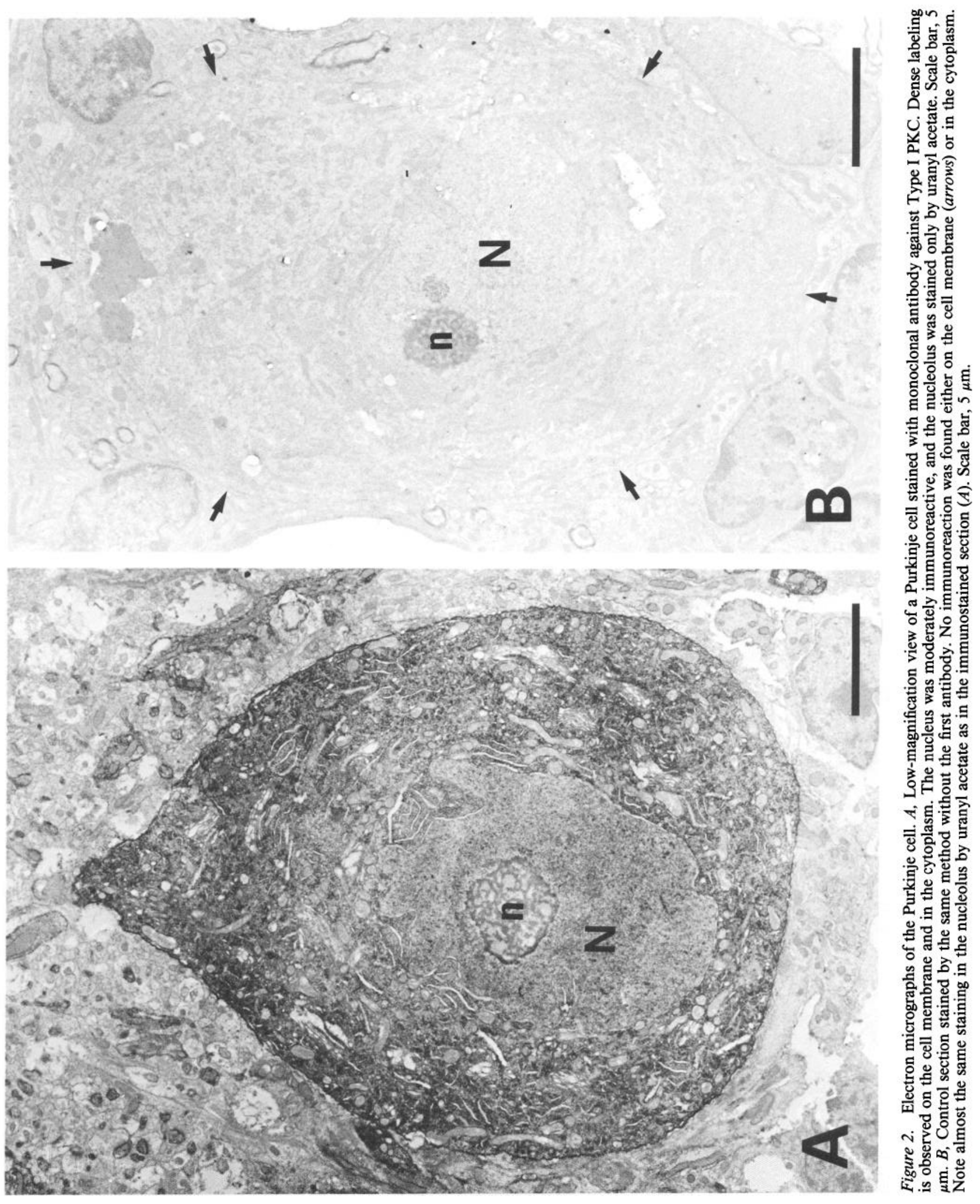




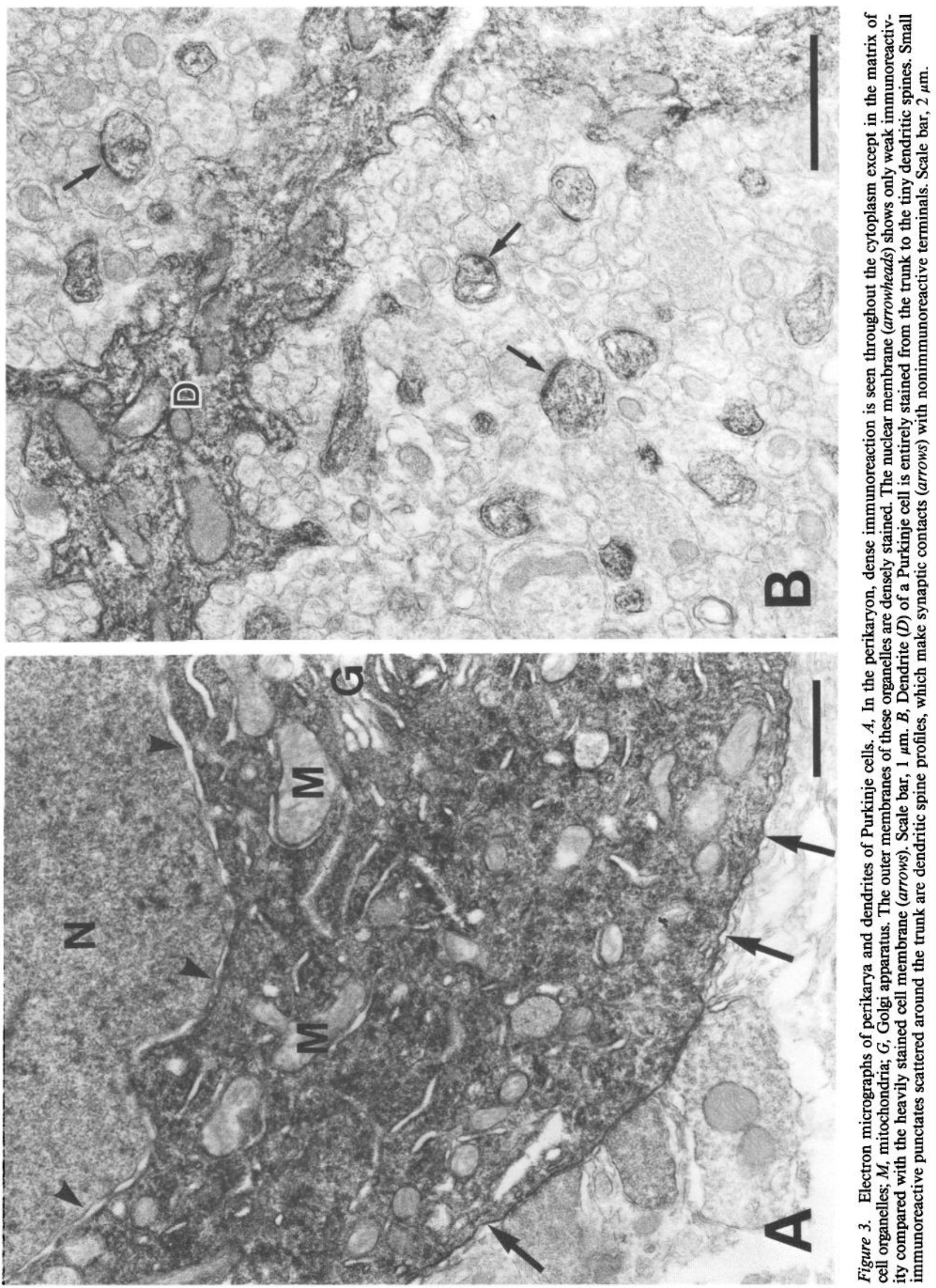


Figure 4. Electron micrograph of a Purkinje cell axon. Immunopositive myelinated axon profile is observed in the white matter of the cerebellar cortex in contrast to the adjacent immunonegative profiles (asterisks). Scale bar, $0.5 \mu \mathrm{m}$. Inset, Light photomicrograph of Purkinje cell axons. Immunopositive axons are seen in the granular layer, running into the white matter of the cerebellar cortex. Scale bar, $100 \mu \mathrm{m}$.

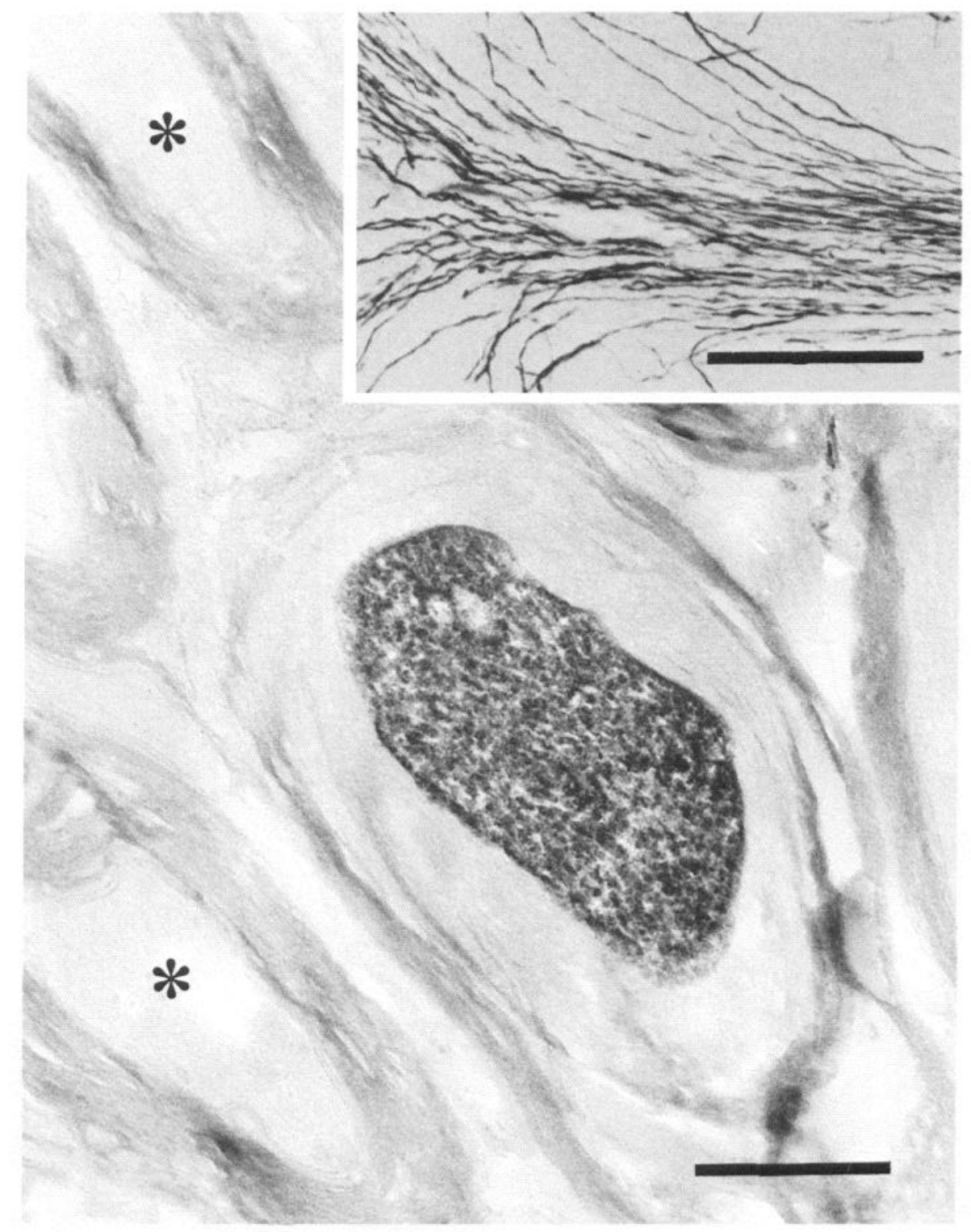

demonstrated that phorbol esters potentiate endogenous GABA release from slices of the deep cerebellar nuclei (unpublished observations).

Kuo and colleagues have reported presynaptic accumulation of the enzyme, as shown here electron microscopically, and in the periphery of the nucleus of several neuronal cells, including Purkinje cells, as well as in glial cells (Girard et al., 1985; Wood et al., 1986). This staining pattern is different from that of $\gamma$-subspecies obtained in the present study. It is probable that their polyclonal antisera have recognized multiple subspecies of the enzyme. Recently, Mochly-Rosen et al. (1987) raised 3 monoclonal antibodies that show different immunostaining patterns in rat brain, although their correspondence to the structurally defined PKC subspecies remains unknown.

The tissue distribution of PKC has been explored by autoradiography with phorbol ester (Worley et al., 1986a, b) and using polyclonal antisera (Girard et al., 1985; Wood et al., 1986) or monoclonal antibodies (Mochly-Rosen et al., 1987). The resolution of the light microscopic autoradiography technique makes it difficult to establish the intraneuronal localization of $\mathrm{PKC}$ as a phorbol ester receptor.

Western blotting and immunoprecipitation have shown that the currently studied antibody (CKI-97) reacts specifically with type I PKC but not with types II and III, which are obtained from brain tissue (Hashimoto et al., 1988). As type I corresponds to the $\gamma$-subspecies but not to the $\beta \mathrm{I}, \beta \mathrm{II}$, and $\alpha$-subspecies expressed in COS 7 cells, the immunoreactivity with CKI-97 shows the presence of $\gamma$-subspecies. It should be mentioned here, however, that immunonegative areas do not always mean absence of the enzyme, since such areas could be caused by technical problems such as fixation and incubation or by the presence of other subtypes of the PKC family.

In this communication, we have described the use of a monoclonal antibody to localize immunoreactive type I PKC molecules in rat Purkinje cells at the electron microscopic level. Subcellular localization of PKC subspecies would provide information toward understanding the complicated functions of PKC. Our results suggest that $\gamma$-subspecies may play important 

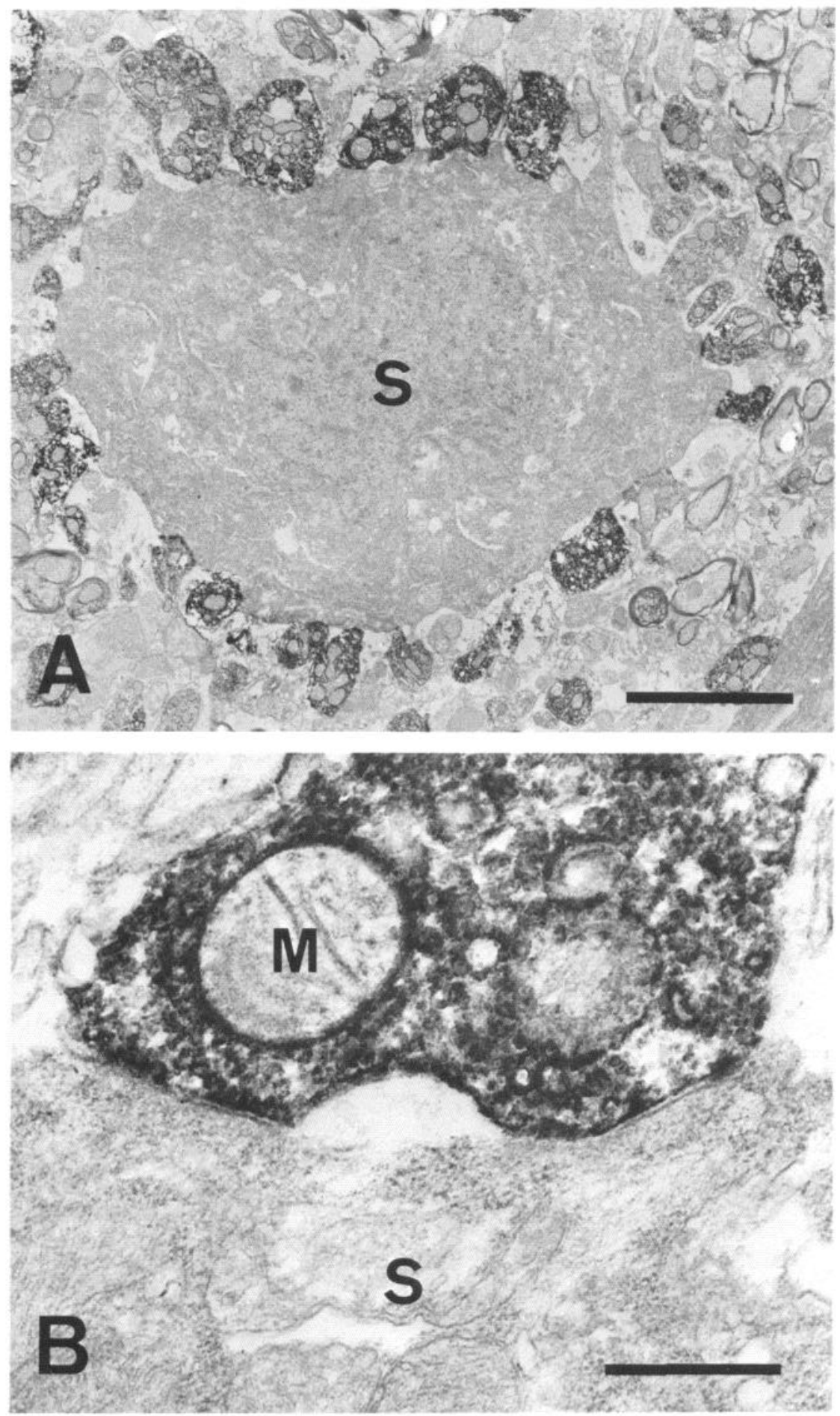

Figure 5. Purkinje cell axon terminals. $A$, Electron micrograph of the cell body $(S)$ in the deep cerebellar nuclei. A large immunonegative cell body $(S)$ is surrounded by immunopositive terminals. Scale bar, $5 \mu \mathrm{m}$. $B$, Immunopositive nerve terminal on the cell body in the deep cerebellar nuclei. Immunopositive terminal makes synaptic contact with the cell body $(S)$. Note the densely labeled terminal filled with vesicles. The outer membranes of the mitochondria $(M)$ are heavily stained. Scale bar, $0.5 \mu \mathrm{m}$. roles in modulation of pre- and postsynaptic functions and nuclear function in the Purkinje cell.

\section{References}

Coussens, L., P. J. Parker, L. Rhee, T. L. Yang-Feng, E. Chen, M. D. Waterfield, U. Francke, and A. Ullrich (1986) Multiple, distinct forms of bovine and human protein kinase $\mathrm{C}$ suggest diversity in cellular signalling pathways. Science $233:$ 859-866.

Girard, P R., G. J. Mazzei, J. G. Wood, and J. F. Kuo (1985) Polyclonal antibodies to phospholipid/ $\mathrm{Ca}^{2+}$-dependent protein kinase and im- munocytochemical localization of the enzyme in rat brain. Proc. Natl. Acad. Sci. USA 82: 3030-3034.

Hashimoto, T., K. Ase, S. Sawamura, U. Kikkawa, N. Saito, C. Tanaka, and Y. Nishizuka (1988) Postnatal development of a brain-specific subspecies of protein kinase $\mathrm{C}$ in rat. J. Neurosci. 8: 1678-1683.

Huang, K.-P., H. Nakabayashi, and F. L. Huang (1986) Isozymic forms of rat brain $\mathrm{Ca}^{2+}$-activated and phospholipid-dependent protein kinase. Proc. Natl. Acad. Sci. USA 83: 8535-8539.

Kikkawa, U., Y. Ono, K. Ogita, T. Fujii, Y. Asaoka, K. Sekiguchi, Y. Kosaka, K. Igarashi, and Y. Nishizuka (1987a) Identification of the structures of multiple subspecies of protein kinase $C$ expressed in rat brain. FEBS Lett. 217: 227-231. 
Kikkawa, U., K. Ogita, Y. Ono, Y. Asaoka, M. S. Shearman, T. Fujii, K. Ase, K. Sekiguchi, K. Igarashi, and Y. Nishizuka (1987b) The common structure and activities of four subspecies of rat protein kinase C family. FEBS Lett. 223: 212-216.

Kitano, T., T. Hashimoto, U. Kikkawa, K. Ase, N. Saito, C. Tanaka Y. Ichimori, K. Tsukamoto, and Y. Nishizuka (1987) Monoclona antibodies against rat brain protein kinase $\mathrm{C}$ and their application to immunocytochemistry in nervous tissues. J. Neurosci. $7:$ 1520-1527.

Knopf, J. L., M.-H. Lee, L. A. Sultzman, R. W. Kriz, C. R. Loomis, R. M. Hewick, and R. M. Bell (1986) Cloning and expression of multiple protein kinase C cDNAs. Cell 46: 491-502.

Kraft, A. S., C. Appling, and R. L. Berkow (1987) Specific binding of phorbol esters to nuclei of human promyelocytic leukemia cells. Biochem. Biophys. Res. Commun. 144: 393-401.

Mochly-Rosen, D., A. I. Basbaum, and D. E. Koshland, Jr. (1987) Distinct cellular and regional localization of immunoreactive protein kinase C in rat brain. Proc. Natl. Acad. Sci. USA 84: 4660-4664.

Nishizuka, Y. (1984a) The role of protein kinase C in cell surface signal transduction and tumour promotion. Nature 308: 693-698.

Nishizuka, Y. (1984b) Turnover of inositol phospholipids and signal transduction. Science 255: 1365-1370.

Nishizuka, Y. (1986) Studies and perspective of protein kinase C Science 233: 305-312.

Ohno, S., H. Kawasaki, S. Imajoh, K. Suzuki, M. Inagaki, H. Yokokura, T. Sakoh, and H. Hidaka (1987) Tissue-specific expression of three distinct types of rabbit protein kinase C. Nature 325: 161-166.

Ono, Y., T. Kurokawa, K. Kawahara, O. Nishimura, R. Marumoto, K. Igarashi, Y. Sugino, U. Kikkawa, K. Ogita, and Y. Nishizuka (1986a) Cloning of rat brain protein kinase $\mathrm{C}$ complementary DNA. FEBS Lett. 203: 111-115.

Ono, Y., T. Kurokawa, T. Fujii, K. Kawahara, O. Nishimura, K. Igarashi, U. Kikkawa, K. Ogita, and Y. Nishizuka (1986b) Two types of complementary DNAs of rat brain protein kinase $\mathrm{C}$, heterogeneity determined by alternative splicing. FEBS Lett. 206: 347-352.

Ono, Y., U. Kikkawa, K. Ogita, T. Fujii, T. Kurokawa, Y. Asaoka, K.
Sekiguchi, K. Ase, K. Igarashi, and Y. Nishizuka (1987a) Expression and properties of two types of protein kinase $C$ determined by alternative splicing from a single gene. Science 236: 1116-1120.

Ono, Y., T. Fujii, K. Ogita, U. Kikkawa, K. Igarashi, and Y. Nishizuka (1987b) Identification of three additional members of rat protein kinase $C$ family: $\delta-, \epsilon-$, and $\zeta$-subspecies. FEBS Lett. 226: 125-128.

Parker, P. J., L. Coussens, N. Totty, L. Rhee, S. Young, E. Chen, S. Stabel, M. D. Waterfield, and A. Ullrich (1986) The complete primary structure of protein kinase $\mathrm{C}$-the major phorbol ester receptor. Science 233: 853-859.

Philippe, J., D. J. Drucker, and J. F. Habener (1987) Glucagon gene transcription in an islet cell line is regulated via a protein kinase C-activated pathway. J. Biol. Chem. 262: 1823-1828.

Saito, N., U. Kikkawa, Y. Nishizuka, and C. Tanaka (1988) Distribution of protein kinase C-like immunoreactive neurons in rat brain. J. Neurosci. 8: 369-382.

Sandoval, M. E., and C. W. Cotman (1978) Evaluation of glutamate as a neurotransmitter of cerebellar fibers. Neuroscience 3: 199-206.

Shearman, M. S., Z. Naor, U. Kikkawa, and Y. Nishizuka (1987) Differential expression of multiple protein kinase $C$ subspecies in rat central nervous tissue. Biochem. Biophys. Res. Commun. 147:911919.

Wood, J. G., P. R. Girard, G. J. Massei, and J. F. Kuo (1986) Immunocytochemical localization of protein kinase $\mathrm{C}$ in identified neuronal compartments of rat brain. J. Neurosci. 6: 2571-2577.

Worley, P. F. J. M. Baraban, and S. H. Snyder (1986a) Heterogeneous localization of phorbol ester receptor binding. J. Neurosci. 6: 199207.

Worley, P. F., J. M. Baraban, E. B. De Souza, and S. H. Snyder (1986b) Mapping second messenger systems in the brain: Differential localization of adenylate cyclase and protein kinase C. Proc. Natl. Acad. Sci. USA 83: 4053-4057.

Young, A. B., M. L. Oster-Granite, R. M. Herndon, and S. H. Snyder (1974) Glutamic acid: Selective depletion by viral induced granule cell loss in hamster cerebellum. Brain Res. 73: 1-13. 